\title{
GEOGRAPHICAL VARIATION AND DISTRIBUTION OF THE BEARDED TIT PANURUS BIARMICUS (LINNAEUS, 1758) (AVES)
}

\author{
by
}

\author{
RONALD SLUYS \\ Institute of Taxonomic Zoology, University of Amsterdam, \\ P.O. Box 20125, 1000 HC Amsterdam, The Netherlands
}

\section{SUMMARY}

The breeding distribution of the Bearded Tit Panurus biarmicus is not disjunct but continuous from western Europe to Manchuria (fig. 4).

Colour variation allows for the partition in a group of light populations, a group of dark populations, and an extra dark population (fig. 5). The range of the dark group is disjunct.

With respect to the amount of streaking on head and back of females, three groups could be distinguished (fig. $6)$. The so-called "variable group" coincides with the dark colour group, except for Greece and the Caucasus, and the "not variable group" coincides with the light colour group.

The marking of individual mantle feathers in females shows no essential differences between populations.

The marking of the outermost tail-feather shows great variability in each population. As a consequence, there are no differences between populations (appendix 3 ).

Apart from sexual dimorphism in plumage, there are also sex-related differences in several biometrical characters (table II).

The so-called dark populations are, as a group, often statistically different from other populations. The light populations, generally, group in the same nonsignificant subsets. Clinal variation in biometrical characters is not pronounced; with respect to males a slight increase in size from west to east may be observed in the characters "tipblack" (fig. 3, A), wing- and tail-length (figs. 7-9).

Three subspecies may be distinguished, viz. Panurus biarmicus biarmicus (Linnaeus, 1758), P. b. russicus (Brehm, 1831), and $P$. b. kosswigi Kumerloeve, 1958 (see fig. 12).

\section{RÉSUMÉ}

La distribution de la Mésange à moustaches Panurus biarmicus en tant qu'oiseau nicheur, n'est pas disjointe mais bien continue d'Europe occidentale à la Manchourie (fig. 4).

La variabilité du coloris permet de distinguer un groupe de populations claires, un groupe de populations foncées, ainsi qu'une population particulièrement foncée (fig. 5). L'aréal du groupe de populations foncées est disjoint.
D'après le nombre des rayures sur la tête et le dos des femelles, il est possible de distinguer trois groupes (fig. 6). Le "groupe variable" coïncide avec le groupe de coloration foncée (exceptions la Grèce et le Caucase), tandis que le "groupe non-variable" coïncide avec le groupe de coloration claire.

Il n'y a pas de différences essentielles entre les populations, en ce qui concerne le dessin des plumes du manteau des femelles.

En ce qui concerne le dessin des plumes rectrices les plus extérieures, il y a variabilité importante dans chaque population. Par contre, il n'y a pas de différences entre populations différentes (appendice 3).

Outre le dimorphisme sexuel du plumage, il y a aussi des différences liées au sexe dans plusieurs caractères biométriques (tableau II).

Les populations désignées comme "foncées" sont, comme groupe, souvent statistiquement différentes d'autres populations. En général, les populations "claires» peuvent être groupées dans les mêmes «subsets" nonsignificatifs. La variabilité clinale des caractères biométriques n'est pas accentuée; en ce qui concerne les mâles, on a pu observer une légère accentuation d'ouest en est des caractères "tip-black» (fig. 3, A), longueur de l'aile et longueur de la queue (figs. 7-9).

Il est possible de distinguer trois sous-espèces, à savoir Panurus biarmicus biarmicus (Linnaeus, 1758), $P$. b. russicus (Brehm, 1831), et $P$. b. kosswigi Kumerloeve, 1958 (voir fig. 12).

\section{INTRODUCTION}

The dispersal behaviour of the Bearded Tit Panurus biarmicus (Linnaeus, 1758) and, as a consequence, its occurrence in previously unoccupied areas, has been the subject of many papers in recent ornithological literature (Axell, 1966; Sell, 1974; Björkman, 1975; Pearson, 1975; Olsson, 1975; Dejonghe, 1976; O'Sullivan, 1976; Marion, 1979; Brichetti \& Di Capi, 1980). Although the ecology and the 
behaviour of the species are well known (Ten Kate, 1931; Koenig, 1951; Spitzer, 1972), no comprehensive study has been published discussing the geographical variation of the Bearded Tit in its entire range. Vaurie (1954, 1959) only gave a short description of the colour variation, while the most recent study is restricted to the western Palearctic (Spitzer, 1973). A thorough biometrical analysis has never been published.

Vaurie (1959) and Dementiev \& Gladkov (1954) only recognized a dark race biarmicus and a paler form russicus. However, Spitzer (1973) recognized a third subspecies, viz. turcestanicus. This author considered the subspecies kosswigi Kumerloeve, 1958, to be one of the two subraces of nominate biarmicus, and used a quaternary nomenclature to describe these subraces. With respect to English and Dutch Bearded Tits, Spitzer (1973) coined a hybridization theory which was widely accepted, but has been rejected recently by Sluys (1982).

The aim of the present paper is to describe the geographical variation of the characters examined, to discuss the subspecific differentiation between the local populations investigated, and to compare my results and views with the literature.

\section{MATERIAL AND METHODS}

The study is based on a total of 397 museum specimens (226 males, 171 females). Sample localities and corresponding sample sizes are shown in fig. 1 and table I.

The following characters were used in this study:

(1) Coloration of head, back, and underparts. The colours of the specimens examined were compared against the following standard specimens:

Males: OA: Rijksmuseum van Natuurlijke Historie, Leiden (RMNH), cat. no. 6, 2-6-1876, Saissan, U.S.S.R. Head very pale grey. Back pale yellow. Belly whitish. Flanks pale pink. Light colour due to wear.

A: Zoölogisch Museum, Amsterdam (ZMA), collection Van Marle, no. 4082, 31-12-1929, Kashgar, Chinese People's Republic. Head pale bluish grey. Back pale cinnamon. Underparts whitish. Flanks pale pink. Thighs as back.

A2: ZMA, collection Van Marle, no. 3536, 31-3-1912, Sarpa, U.S.S.R. Head light grey. Back pale cinnamon-buff. Underparts white. Flanks light pink. Thighs as back.

B: Naturhistorisches Museum, Vienna (NMW), no. 35519, 11-5-1939, Burgenland, Austria. Head light greyish blue. Back cinnamon, tinged grey. Underparts light greyish. Flanks pink. Thighs as back.

C: NMW, no. 34299, 10-11-1923, Neusiedler See, Austria. Head bright blue-grey. Back light orange-brown. Underparts off-white to greyish; lower part of belly pale yellow. Flanks pink. Thighs as back.

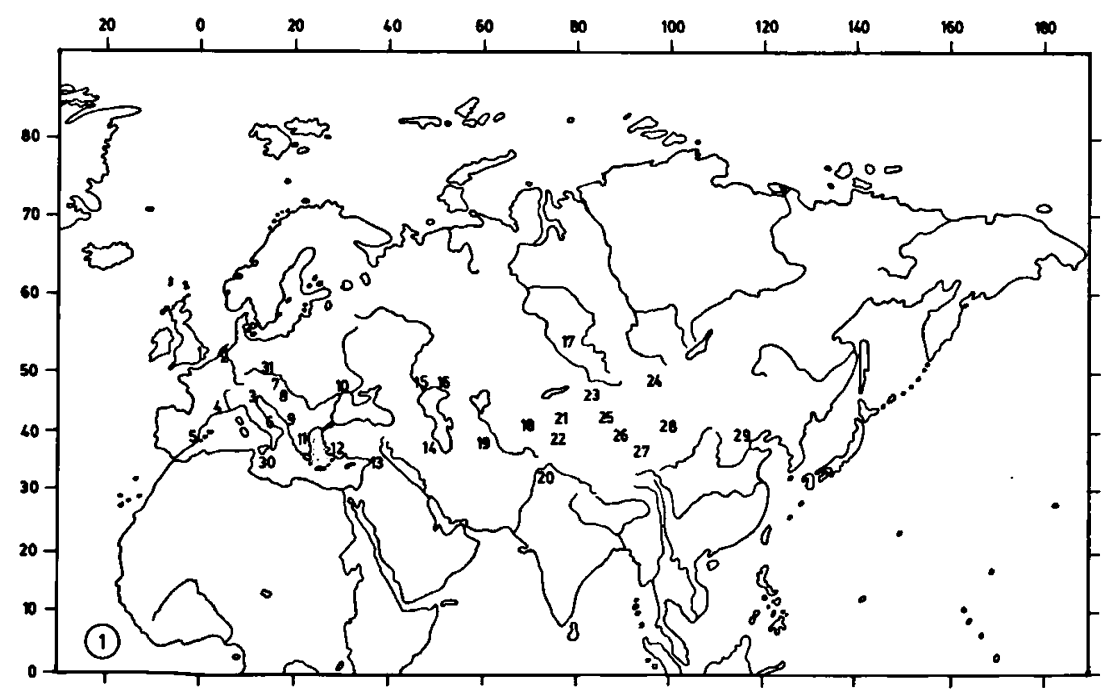

Fig. 1. Map of sample localities. Numbering corresponds with that in table I. 


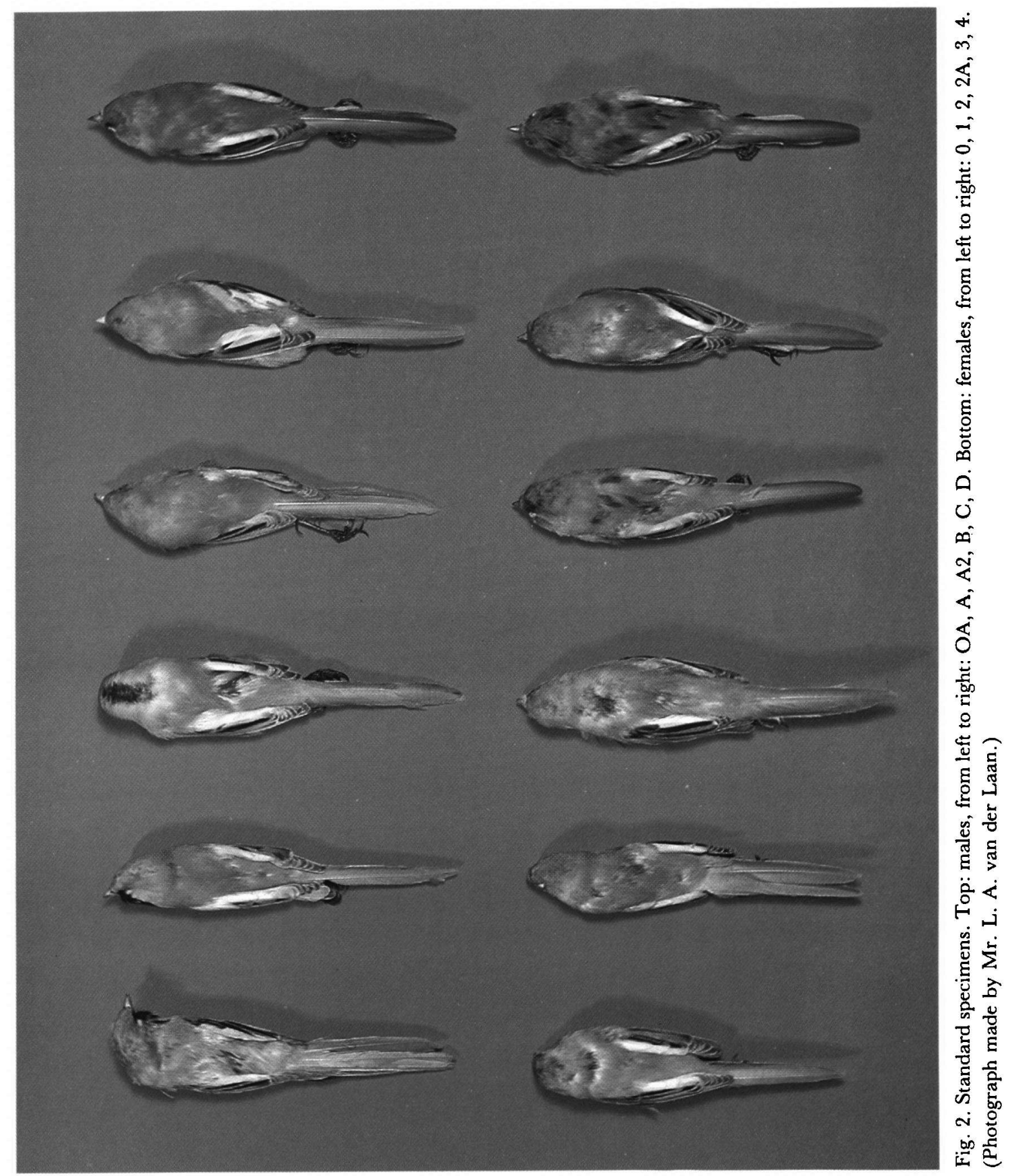


TABLE I

Synopsis of sample localities and number of specimens examined. Breeding period: March to August (Ten Kate, 1931; Spitzer, 1972). Numbering of sample localities corresponds with that in fig. 1.

\begin{tabular}{|c|c|c|c|c|c|c|}
\hline \multirow{3}{*}{$\begin{array}{l}\text { sample } \\
\text { number }\end{array}$} & & \multirow{3}{*}{ abbreviation } & \multicolumn{4}{|c|}{ no. of specimens } \\
\hline & & & \multicolumn{2}{|c|}{ total } & \multicolumn{2}{|c|}{$\begin{array}{l}\text { breeding } \\
\text { period }\end{array}$} \\
\hline & & & males & females & males & females \\
\hline 1 & England & ENG & 21 & 9 & 6 & 6 \\
\hline 2 & The Netherlands & TNL & 28 & 37 & 6 & 2 \\
\hline 3 & Venice & VEN & 18 & 18 & 6 & 6 \\
\hline 4 & Camargue & CAM & 4 & 3 & 2 & 3 \\
\hline 5 & Spain & SPA & 10 & 10 & - & 1 \\
\hline 6 & Foggia & FOG & 6 & 1 & 1 & 1 \\
\hline 7 & Austria & AUS & 5 & 9 & 1 & - \\
\hline 8 & Hungary & HUN & 9 & 9 & 4 & 5 \\
\hline 9 & Albania + Yugoslavia & ALB & 5 & 3 & 5 & 2 \\
\hline 10 & Romania & ROM & 14 & 5 & 10 & 2 \\
\hline 11 & Greece & GRE & 2 & 3 & - & - \\
\hline 12 & Elmali & ELM & 2 & - & 2 & - \\
\hline 13 & Amik Gölü & AMI & 2 & 2 & 2 & 2 \\
\hline 14 & Caucasus (Lenkoran) & CAU & 3 & 1 & 3 & 1 \\
\hline 15 & Astrakhan & AST & 13 & 8 & 9 & 6 \\
\hline 16 & Guryev & GUR & 4 & 1 & $?$ & $?$ \\
\hline 17 & Baraba & BAR & 2 & 3 & 1 & 1 \\
\hline 18 & Tashkent & TAS & 7 & 7 & - & - \\
\hline 19 & Ashkabad + Merw & ASH & 2 & 1 & 1 & - \\
\hline 20 & Attock & ATT & 1 & 2 & - & - \\
\hline 21 & Issykkul & ISS & 23 & 12 & 4 & 2 \\
\hline 22 & Kashgar & KAS & 12 & 11 & 5 & 2 \\
\hline 23 & Saissan-Nor & SAI & 6 & 1 & 4 & 1 \\
\hline 24 & Char-us-Nur & CHA & 1 & 2 & 1 & 2 \\
\hline 25 & Urumchi & URU & 5 & 1 & - & - \\
\hline 26 & Lob-Nor & LOB & 3 & 2 & - & - \\
\hline 27 & Zaidam & ZAI & 3 & - & 1 & - \\
\hline 28 & Edsin Gol & EDS & 9 & 6 & 9 & 6 \\
\hline 29 & Peking & PEK & 4 & 2 & 1 & - \\
\hline 30 & Sicily & SIC & 1 & 1 & $?$ & $?$ \\
\hline 31 & Jericek (N.E. Bohemia) & JER & 1 & 1 & 1 & 1 \\
\hline
\end{tabular}

D: ZMA, no. 30675, 30-9-1975, Zuidelijk Flevoland, The Netherlands. Head dark blue-grey. Back orange-brown. Throat and upperpart of belly off-white; lower part of belly light yellow. Flanks pink. Thighs as back.

Females: 0: ZMA, collection Van Marle, no. 1109, 28-2-1905, Kojsara, U.S.S.R. Head very pale brown. Back sand coloured. Underparts off-white. Flanks very pale pink. Thighs as back.
1: ZMA, collection Van Marle, no. 4084, 12-2-1930, Rabat-Ustang, Chinese People's Republic. Head very pale brown. Back pale sandy, tinged cinnamon. Underparts off-white; lower part of belly pale yellow. Flanks pale pink. Thighs light yellow-brown.

2: ZMA, no. 21286, 15-12-1929, Sroban, Yugoslavia. Head drab buff. Back light cinnamon. Underparts off-white; lower part of belly slightly tinged pale yellow. Flanks very pale pink. Thighs light yellowbrown. 
2A: ZMA, no. 23142, 15-9-1971, Zuidelijk Flevoland, The Netherlands. Head drab buff. Back cinnamon-buff. Underparts whitish. Flanks pink-red. Thighs as back.

3: NMW, no. 34296, 10-11-1923, Neusiedler See, Austria. Head pale brown. Back cinnamon. Underparts pale grey. Flanks pink-red. Thighs cinnamon.

4: ZMA, no. 27602, 12-9-1974, Zuidelijk Flevoland, The Netherlands. Head cinnamon. Back cinnamon-brown. Throat and chest off-white, belly pale yellow. Flanks and thighs brown-orange.

Standard specimens are illustrated in fig. 2. A series of specimens which I had at my disposal for some time was used to supplement the method described above.

(2) Amount of streaking on head and back of females. Expression of the character in the specimens examined was scored against fig. 4 in Spitzer (1973). The notation of scores, however, was that as described by Mead \& Pearson (1974).

(3) Type of marking on the darkest feather on the back of females.

(4) Colour and marking of the outermost tail-feather (t6).

(5) Length of wing - the distance from the carpal joint to the tip of the longest primaries $(p 6, p 7)$ in fully stretched wing.

(6) Length of tail-measured from the point of emergence of the two central tail-feathers to the tip of the longest feather $(t 1)$.

(7) Distance from the tip of secondary 8 to the distal end of black on the feather (see fig. $3, \mathrm{~A}$ ), in the following referred to as "tip-black".

(8) Maximum breadth of black on secondary 8 (see fig. 3,

B), in the following referred to as "breadth".

(9) Nalospi (Prater et al., 1977)-distance from anterior end of nostril to tip of upper mandible.

All measurements are given in $\mathrm{mm}$.

Patterns of character variation among localities were assessed with one-way analysis of variance. If the $F$-ratio indicated significant differences among means, nonsignificant, homogeneous, subsets of means were defined with Duncan's a posteriori multiple range test (cf. Sokal * Rohlf, 1969). Subsets were based on ranked means and not on geographic contiguity of the samples. The probability level used was 0.05 . All statistic analyses were carried out with SPSS programs (Nie et al., 1975).

\section{RESULTS}

\section{Distribution}

Because new information has become available in the literature, the distributional map (fig. 4)

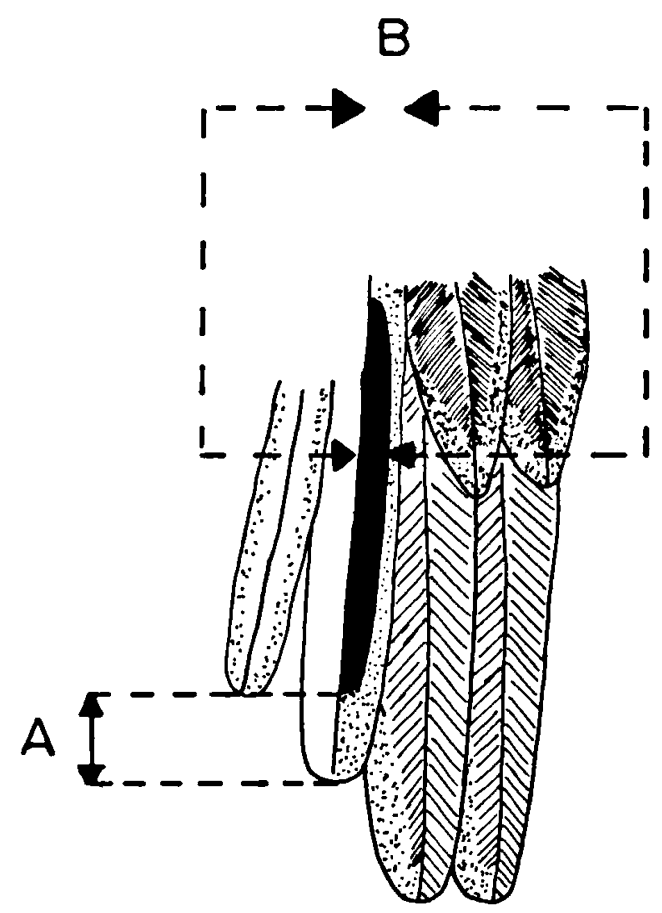

Fig. 3. Biometrical characters measured on secondary 8 . A: "tip-black"; B: "breadth".

differs considerably from that published by Voous (1960). Especially in the Far East, the distribution of the Bearded Tit appears to be continuous instead of disjunct, of course with the restriction that the bird only occurs in suitable habitats, i.e. large reedbeds in freshwater and brackish marshes.

\section{Colour variation}

Representative examples of the results obtained through comparison against standard specimens are given in appendix 1 . These results and the study of series of specimens show that on the basis of head and back colour only three groups may be distinguished, viz. an extra dark, a dark, and a light group.

The extra dark group comprises birds from Amik Gölü, which are easily recognizable by their extreme red-brown colour of back and flanks and the more vivid pink parts on the belly.

The dark group comprises specimens from the following localities: England, The Netherlands, Jericek (N.E. Bohemia, 


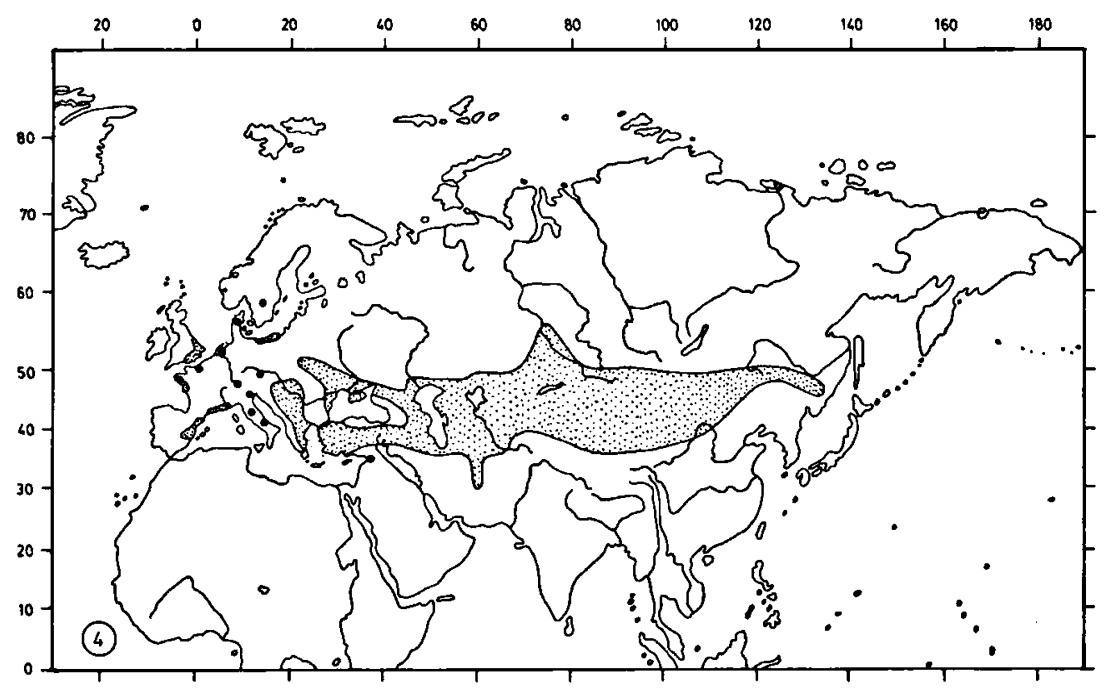

Fig. 4. Breeding distribution of the Bearded Tit (after Voous, 1960; Piechocki \& Bolod, 1972; Vaurie, 1972; Björkman, 1975; Olsson, 1975; Massa, 1976; Matvejev, 1976; Sharrock, 1976; Tso-Hsin, 1976; Yeatman, 1976; Beaman, 1978; Marion, 1979; Klafs \& Stübs, 1979; Brichetti \& Di Capi, 1980; Guermeur \& Monnat, 1980; Schifferli et al., 1980).

Czechoslovakia), Spain, Camargue, Foggia, Venice, Greece, and the Caucasus. Although no skins were available, there is reason to believe that Bearded Tits from Sweden, Denmark, northern Germany and Poland, northern France, and Switzerland also belong to the dark group. Almost certainly these populations were founded by Dutch stragglers, as the build-up of populations in Sweden, Germany, Denmark, and Switzerland coincides with eruptions of the Dutch breeding population (Bengtson, 1967; Björkman, 1975; Olsson, 1975; Klafs \& Stübs, 1979; Schifferli et al., 1980). In Mecklenburg (East German Democratic Republic) and Brittany (France) ringing results confirm the Dutch origin of these populations (Klafs \& Stübs, 1979; Marion, 1979).

Among these dark populations only minor and gradual variation in colour may be discerned. In males, birds from Jericek, Foggia, and Greece have a slightly darker head compared with birds from The Netherlands and Venice; the head colour of the Caucasus males is slightly paler than that of males from Jericek, Foggia, and Greece.

According to Vaurie $(1954,1959)$ Bearded Tits from the Mediterranean and the Adriatic are lighter than birds from The Netherlands, England, and Germany. My observations are discordant with Vaurie's statement. Males from Venice (including several specimens of "occidentalis" collected by Tschusi) have a head and back colour similar to that of dark Dutch males, while Spanish Bearded Tits are as dark as specimens from The Netherlands, and Venice. Thus, males from the Mediterranean and the Adriatic are not paler than birds from northern breeding areas, but they are similar to the dark specimens from these northern populations. The Albanian population forms an exception in that it occupies an intermediate position: in certain characters it is paler than specimens from the dark populations and similar to birds from Austria, Hungary, and Romania (coloration of head and back in males and females), while another character indicates resemblance to specimens from dark populations, viz. coloration of underparts in males.

Vaurie (1959) and Spitzer (1973) included Bearded Tits from Azerbaidzhan and the Caucasus in the subspecies russicus, implying that these birds are as pale as specimens from Austria which they also considered russicus. However, I found that birds from the Caucasus 
are darker than birds from eastern Europe, Transcaspia, and Turkestan and only slightly paler than Bearded Tits from The Netherlands and Venice (differences especially marked with respect to the head colour). Keve (1943) already noticed that birds from the Caucasus were slightly paler than specimens from Italy and Greece, but darker than birds from Dalmatia, Hungary, Galicia, and Turkestan.

Some differences in coloration may be distinguished among the light populations. Males from Yarkand have a slightly darker head than males from eastern Europe, Transcaspia, southern Russia, Tien-Shan, and Saissan. Males from Peking show a back colour which is similar to that of specimens from Urumchi, but slightly darker compared with birds collected in other parts of Turkestan. Females from Peking are also slightly darker than specimens from Turkestan. The colour differences are, however, very slight. Vaurie $(1954,1959)$ already noticed the slightly darker coloration of Bearded Tits from the Far East. According to Vaurie (1954), Bearded Tits from Dobrogea (Romania) are slightly darker than those from the lower Volga. My study reached similar conclusions, except in back colour of males which is alike in both populations. Female Bearded Tits from Romania, Hungary, and Astrakhan are slightly less sandy than birds from Turkestan and Mongolia. Birds from Austria are slightly darker than specimens from Hungary and further east.

Conclusions concerning colour variation are summarized in fig. 5 .

\section{Streaking on head and back of females}

The results are expressed in the form of crosstables; representative examples are listed in appendix 2.

The greatest amount of streaking is shown by females from England, Sweden (Björkman, in litt.), The Netherlands, Camargue, Spain, and Venice and, to a lesser extent, birds from Romania and Albania. These populations are also characterized by the occurrence of females with varying amounts of streaking, i.e. birds with no streaking, weak streaking, as well as birds with heavy streaking on head and back. However, some feathers with black shaft streaks are also present in part of the females from the following localities: Austria, Hungary, Greece, Amik Gölü, Caucasus, Astrakhan, Issykkul, Tashkent, Kashgar, Char-us-Nur, Edsin Gol, Saissan-Nor, Urumchi, Attock, and Peking.

These results contradict Spitzer's (1973) statement that females from populations east of

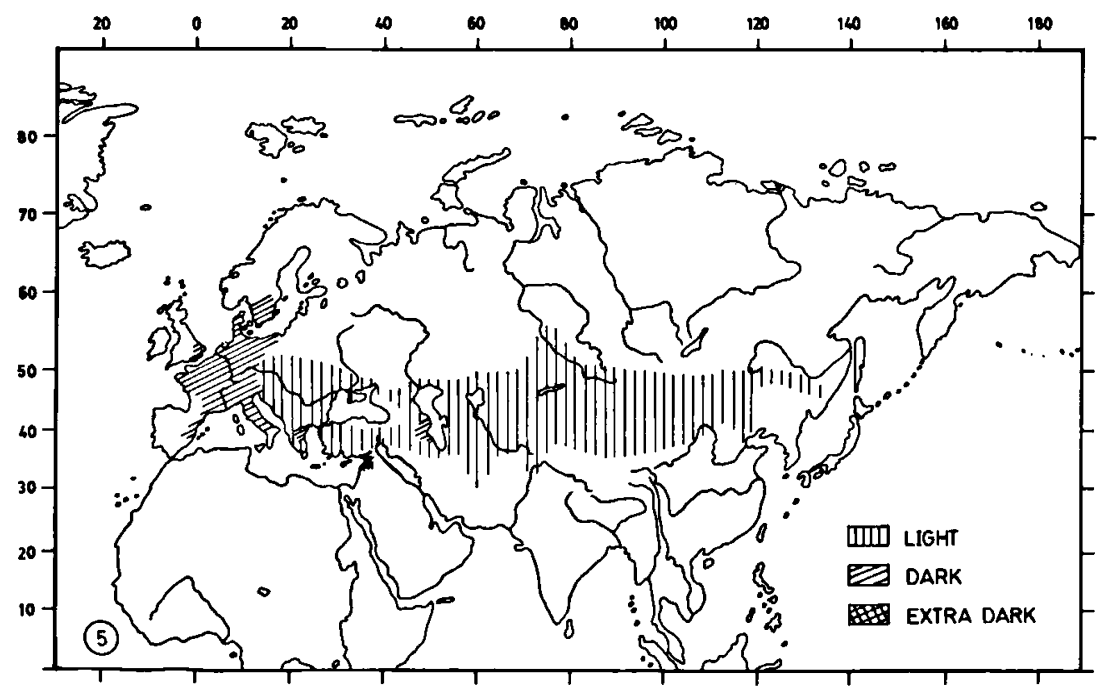

Fig. 5. Geographical distribution of the three colour groups. Vertical hatching: range of light populations; diagonal hatching: dark populations; cross hatching: extra dark population. 
the Caspian Sea ("turcestanicus") show no black shaft streaks and thus have unstreaked upperparts. Also in contradiction with Spitzer's (1973) findings is the presence of weak streaking on the backs of the two only known female representatives of the Amik Gölü population.

On the basis of amount of streaking on head and back of females, three groups of local populations may be distinguished. The first group of populations may be called the "variable group" and is characterized by the occurrence of females with no streaking as well as females with heavy streaking, and all combinations between these two extremes (i.e., score $0 / 0$ to $3 / 2$ ). Another group may be called "not or hardly variable group", being characterized by the occurrence of unstreaked or almost unstreaked females (i.e., score $0 / 0$ to $0 / 1)$. A third group may be called "intermediate"' between the other two groups. Fig. 6 shows which populations belong to each of these three groups.

\section{Marking of dark mantle feathers in females}

The amount of streaking on the back of female Bearded Tits is directly correlated with the marking of individual feathers. If there are no black shaft streaks, the upperparts show no streaking because the black featherbases are not revealed. The results of this part of the study are paralleled by those described in the previous section. In almost every population examined, females were found of which some mantle feathers showed black shaft streaks. Moreover, in the greater part of the populations, females with various kinds of shaft streaks were represented: no shaft streaks, partial streaks (sometimes small), and large shaft streaks. Thus, it may safely be concluded that the marking of individual mantle feathers of female Bearded Tits shows no essential differences between populations. What differs between populations are the number of dark feathers (i.e., with shaft streaks) in individual females and the number of females having dark mantle feathers. In the western populations almost every female shows some feathers with dark shaft streaks, while in the eastern populations only a minority of the females shows these. In the eastern populations, females with dark feathers can be found after examination of a large series of skins, as is true for finding unstreaked females in western populations.

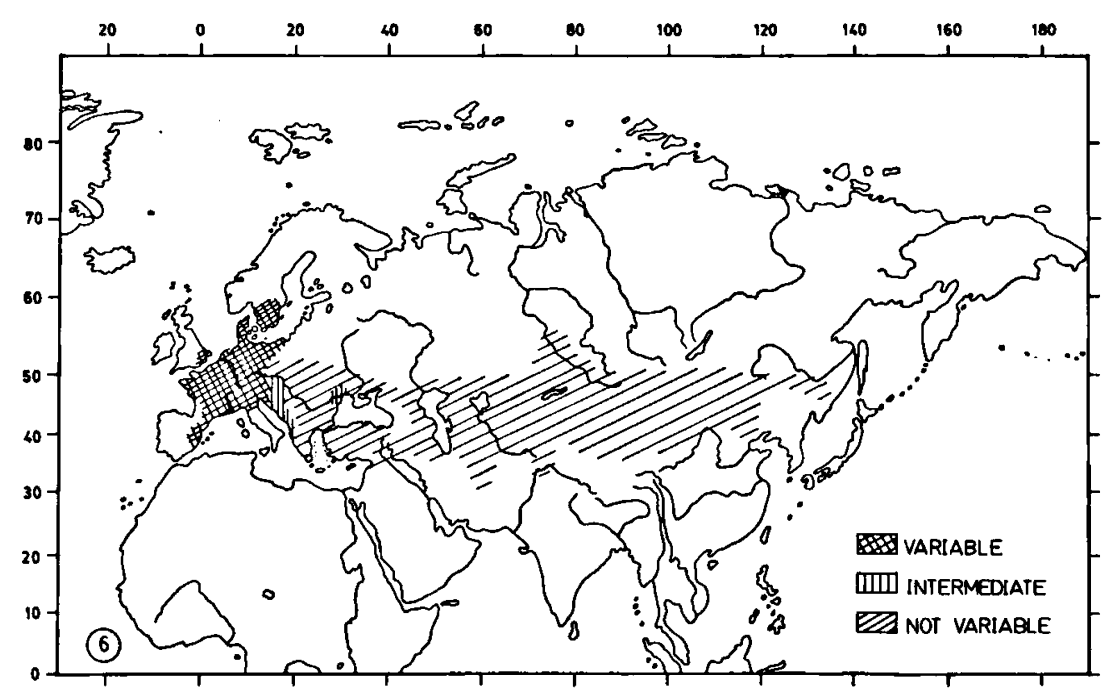

Fig. 6. Streaking on head and back of females. Cross hatching: variable populations (score $0 / 0$ to $3 / 2$ ); vertical hatching: intermediate populations (score $0 / 0-2 / 1$ $-0 / 2$ ); diagonal hatching: not variable populations (score $0 / 0-0 / 1$ ). 


\section{Outermost tail-feather}

From appendix 3, which shows representative examples of populations examined, it is apparent that there exists in each population a great variability in the markings of $t 6$. As a consequence, there are no differences among populations or groups of populations.

This conclusion is entirely different from that of Spitzer (1973). He distinguished four types of outer tail-feathers. In Spitzer's fig. 1c, the intensity of brown in certain russicus specimens is exaggerated. None of the specimens examined from eastern Europe showed a dark brown colour on the distal part of the inner web. In all cases in which some coloration could be discerned, it was light cinnamon. According to Spitzer (1973), “turcestanicus", i.e. birds from populations east of the Caspian Sea, has no cinnamon hue on the distal part of the inner vane. However, this appears to be the case only in part of the eastern birds, and to be variable within local populations.

\section{Sexual dimorphism}

Mensural variation was studied separately for males and females because of sex-related differences between the means of several characters (table II). Males are on the average somewhat larger than females. Statistically significant sex-related differences have been demonstrated also by Sell (1974), and are indicated in Marion's (1979) diagrams.

\section{Sample comparisons}

Univariate analysis of variance revealed for males and females statistically significant differences between locality means (table III). Results of interlocality comparisons are shown in figs. 7-11.

\section{DISCUSSION}

In a study of the geographical variation of a species, one or more characters may be used to distinguish one or more groups of populations

\section{TABLE II}

Averages of six characters of Bearded Tits (28 males, 37 females) collected in The Netherlands, Student's $t$ values, degrees of freedom, and levels of significance for differences among means of both sexes.

\begin{tabular}{|c|c|c|c|c|}
\hline \multirow[b]{2}{*}{ character } & \multicolumn{2}{|c|}{ mean } & \multirow[b]{2}{*}{$d f$} & \multirow[b]{2}{*}{$t$} \\
\hline & males & $\overline{\text { fernales }}$ & & \\
\hline wing length & 60.75 & 59.13 & 62 & $5.79^{* * *}$ \\
\hline tail length & 78.25 & 72.42 & 62 & $8.30^{* * *}$ \\
\hline tarsus length & 21.22 & 20.61 & 39 & $3.39^{* *}$ \\
\hline tip-black & 3.49 & 2.88 & 61 & $2.97^{* *}$ \\
\hline breadth & 2.69 & 2.54 & 59 & $2.02^{* *}$ \\
\hline nalospi & 5.93 & 5.64 & 43 & $4.40^{* * *}$ \\
\hline
\end{tabular}

${ }^{* *} p<0.01 ; * * * p<0.001$.

TABLE III

Results of analysis of variance.

\begin{tabular}{lcclll}
\hline & \multicolumn{2}{c}{$d f$} & & \multicolumn{2}{c}{$F$} \\
\cline { 2 - 3 } \cline { 5 - 6 } source of variation & males & females & & males & females \\
\hline wing length & $28 / 193$ & $26 / 136$ & & $8.37^{* * *}$ & $8.04^{* * *}$ \\
tail length & $28 / 170$ & $25 / 108$ & & $5.17^{* * *}$ & $5.67^{* * *}$ \\
tip-black & $27 / 174$ & $24 / 126$ & & $4.38^{* * *}$ & $6.39^{* * *}$ \\
breadth & $28 / 189$ & $26 / 136$ & $6.83^{* * *}$ & $3.76^{* * *}$ \\
nalospi & $26 / 156$ & $24 / 101$ & $3.23^{* * *}$ & $3.90^{* * *}$ \\
\hline
\end{tabular}

*** $p<0.001$

from the rest and to describe them on subspecies level. It is my opinion that in this respect nonbiometrical characters should only be used if diagnostic, while biometrical characters may be used to describe a subspecies when differences between averages are statistically significant.

With respect to the present study, it is clear that of the nonbiometrical characters the marking of $t 6$ cannot be used diagnostically because all populations examined showed a similar pattern of variation. This conclusion is contrary to that of Spitzer (1973), who used different marking of $t 6$ to characterize the subspecies turcestanicus. Other characters will be discussed below. 
Surveying the results of the colour variation, it is apparent that the range of the so-called dark group (see fig. 5) is disjunct. Bearded Tits from Greece and the Caucasus are separated from the main area of distribution. Keve (1943) considered Caucasus specimens to be sufficiently different to assign them to $P$. $b$. alexandrovi Zarudny \& Bilkewitsch, 1916. In my opinion this subspecific distinction is not warranted because colour differences are slight, while some of the Caucasian specimens even are identical in coloration to birds from The Netherlands and Venice. Moreover, the greatest difference concerns the head colour of the males, of which Keve (1943) made no mention.

Neither is the situation made clear by including the Bearded Tits from the Caucasus in the subspecies russicus on the ground of their coloration (cf. Vaurie, 1959; Spitzer, 1973). The colour of the back in Caucasus birds is considerably darker than in Bearded Tits from eastern Europe. Therefore, the situation is described best by combining the population from the Caucasus with the dark group. The Bearded Tits from the Caucasus are not biometrically different from the majority of the dark populations.

Apart from Greece and the Caucasus, all dark populations coincide with the group in which females show variable streaking on head and back (fig. 6; Caucasus assigned to "not variable group" on the basis of a single female).

With regard to the biometrical characters, the dark populations as a group are often significantly different from other populations.

In view of the above it may be concluded that the so-called dark populations show a similar pattern of variation in several characters and can be distinguished from other populations. Of course, these Bearded Tits should be considered as $P$. b. biarmicus (Linnaeus, 1758).

Considering the colour of both sexes and the amount of streaking on the back of the female examined (score 0/2), Bearded Tits from Sicily formerly belonged to this subspecies. This population disappeared after 1958 (Massa, 1976).
According to Vaurie (1959), Bearded Tits from Yugoslavia and Albania also belong to the dark subspecies biarmicus. However, this is hardly justified by their colour. Birds from Yugoslavia and Albania belong to the group of light populations.

The exceptionally dark Bearded Tits from Amik Gölü have been described as $P$. $b$. kosswigi Kumerloeve, 1958. Indeed, their red-brown colour makes it possible to distinguish these birds immediately. According to Spitzer (1973) the female specimens differ from those of the nominate race in the absence of feathers on the back with dark shaft streaks. However, this is incorrect because (1) the two females from Amik Gölü do have feathers on the back with dark shaft streaks, and (2) females without any streaking on head and back also occur in the nominate race.

When the Amik Gölü population is compared with the dark group it appears to be biometrically different only from the Spanish population in mean length of wing in males and females and mean length of tail in males. With respect to the last-mentioned character there is also a statistically significant difference between Amik Gölü and The Netherlands. Spitzer's (1973) remark that kosswigi has perhaps slightly longer wings than birds from the western Mediterranean, holds true only with regard to Spanish Bearded Tits.

The group of light populations cannot be subdivided on the ground of colour variation. Colour differences among populations are too slight and not constant. With respect to streaking of head and back in females, the group of light populations coincides with that of the "not variable group", except for Albania, Austria, and Romania, which fall in the "intermediate group". This is paralleled by the fact that East European Bearded Tits are sometimes slightly darker than birds from more easterly located populations.

Generally, the light populations group in the same homogeneous subsets (figs. 7-11). Within the light colour group some populations are 

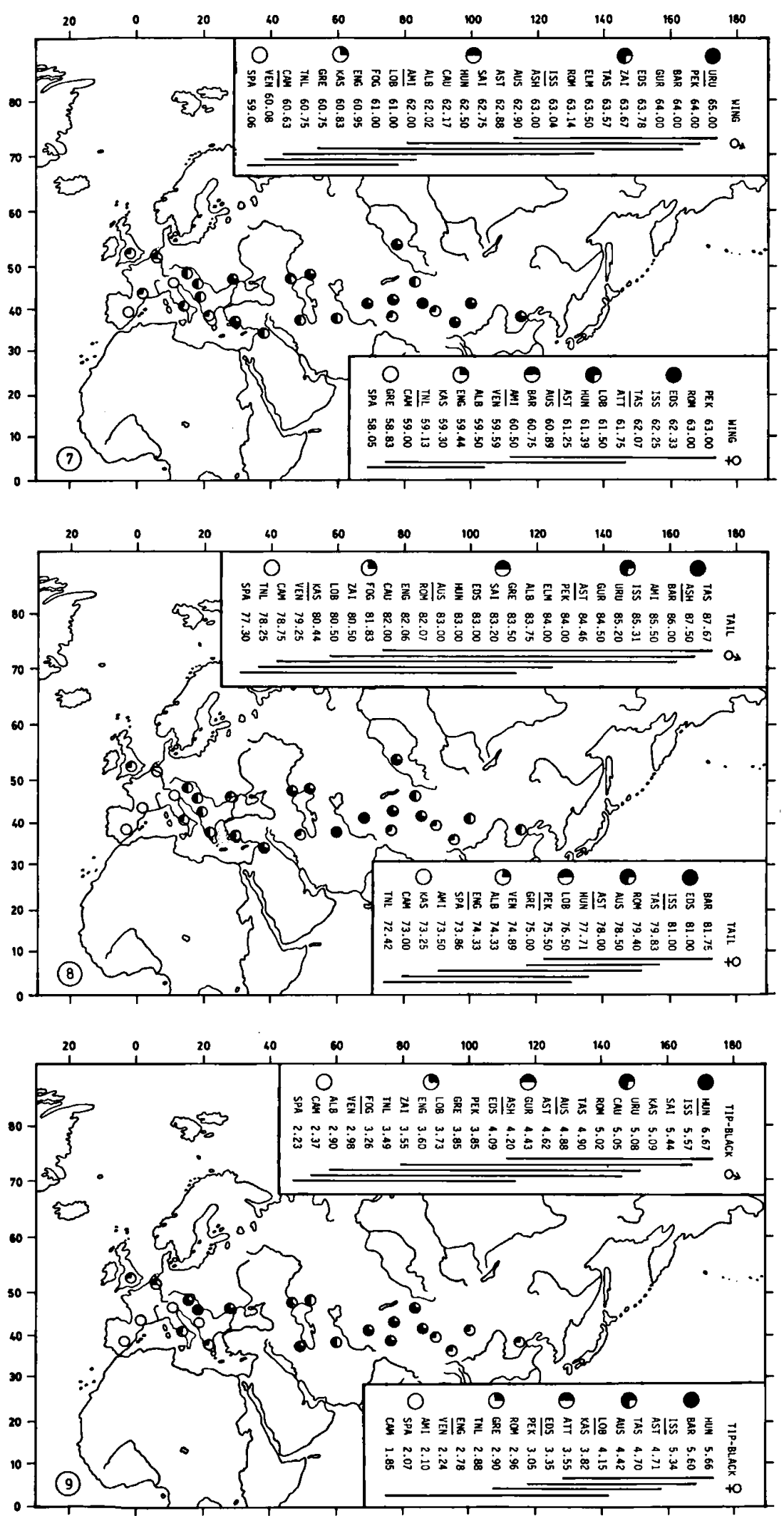

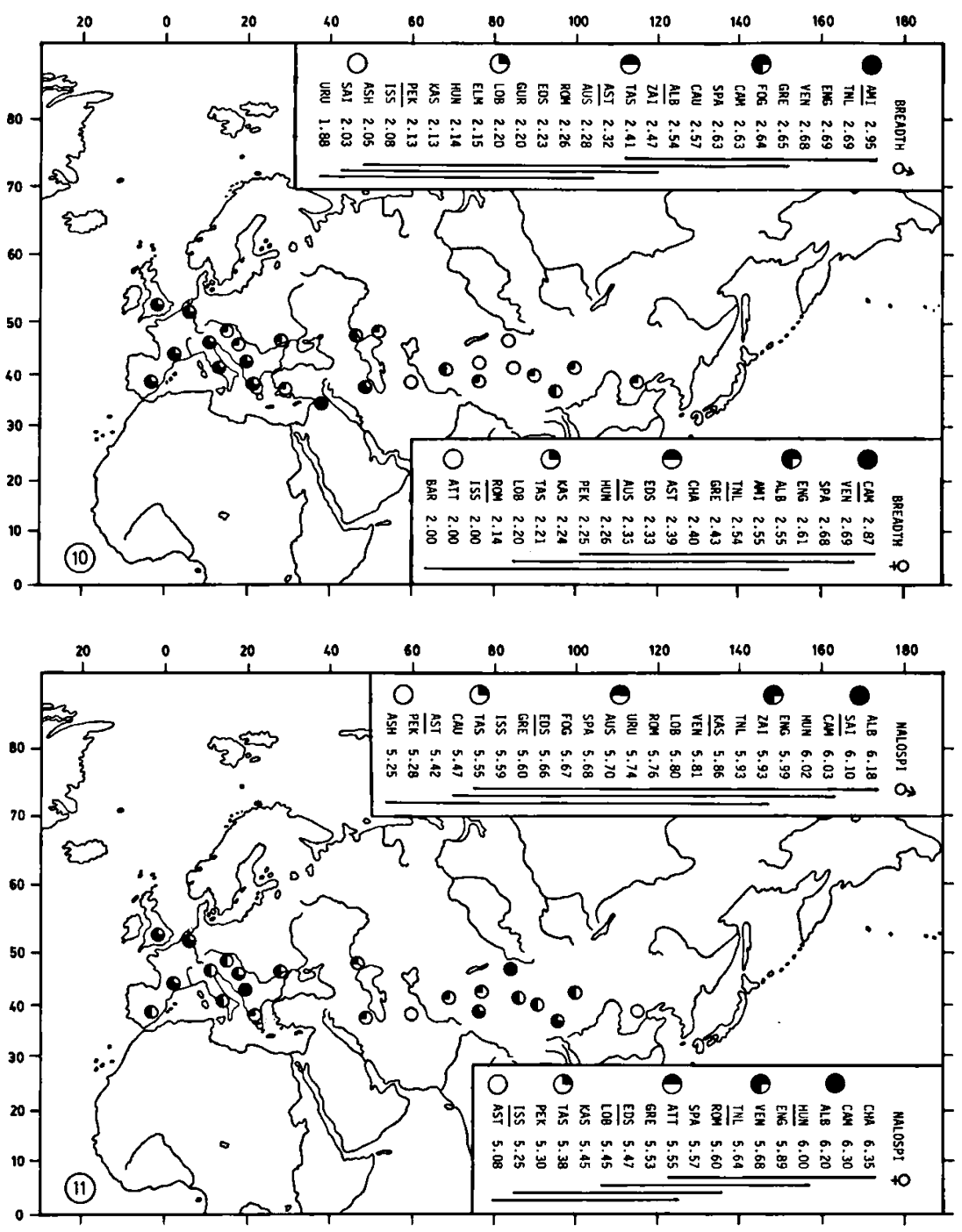

Figs. 7-11. Geographic variation in wing- and tail-length, "tip-black", "breadth", and nalospi. Vertical lines represent nonsignificant, homogeneous, subsets of locality means, resulting from comparisons by DUNCAN procedure (probability level: 0.05). Variously shaded circles at each locality indicate trends in character variation (localities with identical symbols are delimited by short lines). Pie symbols do not correspond with homogeneous subsets. Solid circles represent the largest means, open circles the smallest; intermediate values are denoted by three-quarters, half, and one-quarter solid circles. Only data for males are plotted on the maps. 
significantly different from the rest in only one biometrical character. There is no geographically homogeneous group of populations which is statistically different from the rest of the light populations.

Spitzer's (1973) statement that in both sexes “turcestanicus"' (i.e., populations east of the Caspian Sea) has a significantly larger wing than russicus, is in general incorrect. Only with respect to certain characters do some russicus and "turcestanicus" populations show statistically significant differences between means. On the other hand, however, certain russicus populations also show statistically significant differences among means. Consequently, the group of light populations cannot be subdivided on the grounds of colour or biometrical variation. Bearded Tits belonging to these populations should be assigned to $P$. b. russicus (Brehm, 1831); recognition of the race turcestanicus is not warranted.

Interpretation of the results of a posteriori tests is generally difficult because homogeneous subsets do not always correspond with geographically contiguous sample localities, and because of overlapping subsets.

Relatively few populations are significantly different in mensural characters from the remaining samples. In most cases only samples with extreme averages are significantly different from each other. Although never very marked, some biometrical characters show clinal trends in variation. With respect to males, a slight increase in size from west to east is shown by the characters wing- and tail-length, and "tipblack" (figs. 7, 8, 9). However, the clines are not very pronounced, either because increase in size only occurs over a geographically short distance, or because certain populations disturb the cline with their greater or smaller averages. With respect to "tip-black" in males (fig. 9) the sample means may be grouped into three sets: one comprises western populations, including Albania and Greece, with small means, the second one a large group of eastern populations (up to ca. $85^{\circ} \mathrm{E}$ ) with moderate to large means, while the third set includes more easterly located populations which are characterized by small means. Remarkable is the large mean of the Hungarian sample. In females this tripartition is less pronounced.

Concerning the character "breadth" (fig. 10), the dark populations and also the Albanian one show large means, in contrast to the light populations which show moderate to small means. With respect to nalospi (fig. 11), variation in averages is not confined to certain geographically contiguous areas.

Not discussed in the above is a male specimen from the Luganskaya District, U.S.S.R. (British Museum (Natural History) coll. no. 1941:5:30-8011). This bird is exceptionally pale; it is as pale as standard specimen OA, but the feathers are not worn. The upperparts are considerably paler as compared with specimens from N.W. Mongolia and Turkestan. It is not known whether this bird is an aberrant individual or is representative of the entire local population.

This study results in the recognition of three subspecies, viz. $P$. b. biarmicus (Linnaeus, 1758), P. b. russicus (Brehm, 1831), and P. b. kosswigi Kumerloeve, 1958; their respective ranges are summarized in fig. 12.

\section{ACKNOWLEDGEMENTS}

I am grateful to the curators of the following museums for the opportunity they gave me to study the collections under their care or for sending skins: Universitetets Zoologiske Museum, Copenhagen (J. Fjeldså), Zoologisches Forschungsinstitut und Museum Alexander Koenig, Bonn (H. E. Wolters), Rijksmuseum van Natuurlijke Historie, Leiden (G. F. Mees), NaturMuseum und Forschungsinstitut "Senckenberg", Frankfurt am Main (D. S. Peters), Martin LutherUniversität, Sektion Biowissenschaften, Halle-Wittenberg (R. Piechocki), Staatliches Museum für Tierkunde, Dresden (S. Fck), Naturhistorisches Museum, Vienna (H. Schifter), Museo Civico di Storia Naturale, Milan (L. Cagnolaro), Zoologisches Museum an der HumboldtUniversität, Berlin (G. Mauersberger), Zoologische Sammlung des Bayerischen Staates, Munich (J. Reichholf), Muséum National d'Histoire Naturelle, Paris (C. Jouanin), British Museum (Natural History), Tring 


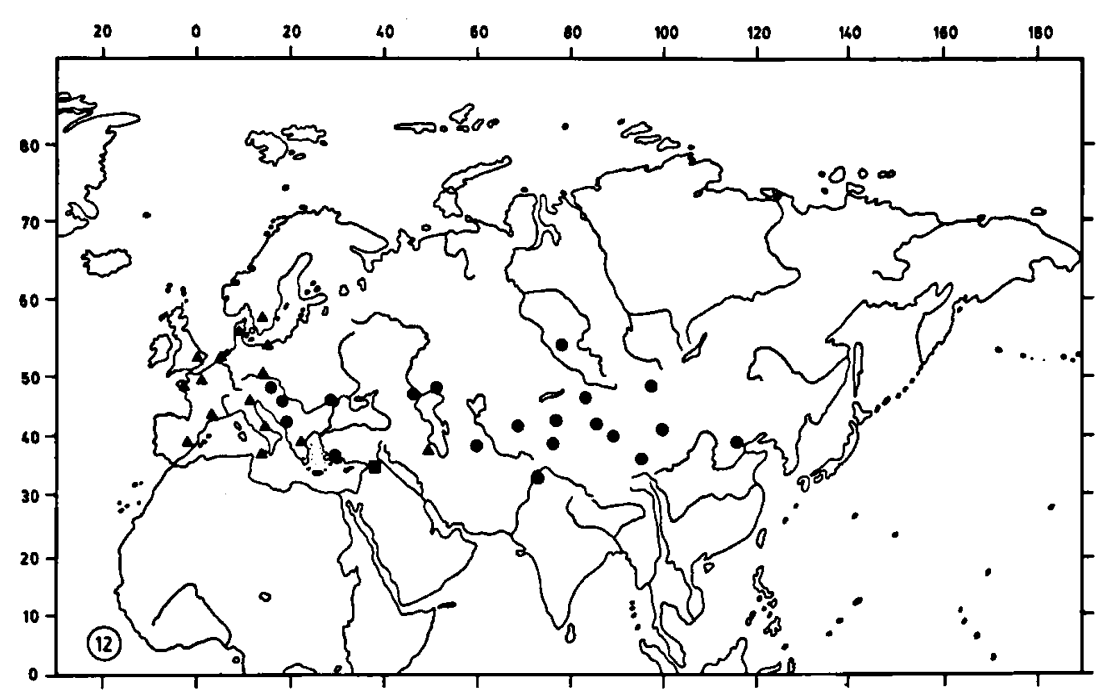

Fig. 12. Distribution of: $\mathbf{\Delta}$ : Panurus b. biarmicus, $\bullet:$. b. russicus, $\square:$ P. b. kosswigi.

(I. C. J. Galbraith), Università di Palermo-Istituto di Zoologia, Palermo (B. Massa).

I would like to thank Dr. J. Wattel for his comments on the manuscript and Anthony $\mathrm{H}$. James for checking the English text. With respect to the publication of the colour plate (fig. 2), I wish to acknowledge the financial support of the M.A.O.C. Gravin van Bylandt Stichting, the P.A. Hens Memorial Fund, and the Vakgroepfonds Bijzondere Dierkunde-Artis Bibliotheek.

\section{REFERENCES}

Axell, H. E., 1966. Eruptions of Bearded Tits during 1959-65. Br. Birds, 59: 513-543.

Beaman, M. (ed.), 1978. Panurus biarmicus (Bearded Reedling). Bird Rep. orn. Soc. Turk., 4: 186.

Bengtson, S. A., 1967. Skäggmesen (Panurus biarmicus) i Skäne 1965-66 en för landet ny fảgelart. Vår Fågelvärld, 26: 244-248.

Björkman, G., 1975. The Bearded Tit in Lake Tåkern. Vår Fågelvärld, 34: 296-310.

Brichetti, P. \& C. di CAPI, 1980. Ricomparsa del Basettino (Panurus biarmicus) come nidificante, sul Lago Superiore di Mantovia (Lombardia, Italia). Riv. ital. Orn., 50: 26-34.

Dejonghe, J. F., 1976. Hivernage et données biométriques de la Mésange à moustaches (Panurus biarmicus) en Île-de-France. Passer, 13: 77-85.

Dementiev, G. P. \& N. A. Gladkov (eds.), 1954. Birds of the Soviet Union, 5: 1-957 (Israel Program for Scientific Translations, Jerusalem).

Guermeur, Y. \& J. Monnat (eds.), 1980. Histoire et géographie des Oiseaux nicheurs de Bretagne: 1-240 (Soc. pour l'étude et la protection de la nature en Bretagne, Centrale ornith. Bretonne-Ar Vran).
Kate, C. G. B. ten, 1931. Zur Brutbiologie von Panurus biarmicus biarmicus (L.). Beitr. FortpflBiol. Vögel, 7: 1-10, I-IV.

KEVE, A., 1943. Einige systematische Bemerkungen über das ungarische ornithologische Material in der Sammlung des Wiener Naturhistorischen Museums. Aquila, 50: 307-310.

Klafs, G. J. Stübs (eds.), 1979. Die Vogelwelt Mecklenburgs: 1-358 (Gustav Fischer Verlag, Jena).

Koenig, O., 1951. Das Aktionssystem der Bartmeise (Panurus biarmicus L.). Öst. zool. Z., 3: 1-82; 247325.

Kumerloeve, H., 1958. Eine neue Bartmeisenform vom Amik Gölü (See von Antiochia). Bonner zool. Beitr., 9: 194-199.

Marion, L., 1979. Statut actuel des populations de Mésanges à moustaches Panurus biarmicus (L.) en France et dans le reste de l'Europe. Bull. Soc. Sci. nat. Ouest Fr., (N. S.) 1: 106-145.

MAsSA, B., 1976. Considerazioni sulla situazione dell'avifauna Siciliana problemi di conservazione. Ric. Biol. Selvag., 8 (Suppl.): 427-470.

Matvejev, S. D., 1976. Survey of the Balkan peninsula bird fauna, part I: 1-365 (Serbian Acad. Sci. and Arts, Beograd).

Mead, C. J. \& D. J. Pearson, 1974. Bearded Reedling populations in England and Holland. Bird Study, 21: 211-214.

Nie, N. H., C. H. Hull, J. G. Jenkins, K. Steinbrenner D. H. BENT, 1975. SPSS, statistical package for the social sciences (2nd ed., 1975): i-xxiv, 1-675 (McGraw-Hill, New York etc.).

Olsson, V., 1975. Bearded Reedling populations in Scandinavia. Bird Study, 22: 116-118.

O'Sullivan, J. M., 1976. Bearded Tits in Britain and Ireland, 1966-1974. Br. Birds, 69: 473-489. 
Pearson, D. J., 1975. Moult and its relation to eruptive activity in the Bearded Reedling. Bird Study, 22: 205-227.

Piechocki, R. \& A. Bolod, 1972. Beiträge zur Avifauna der Mongolei, Teil II, Passeriformes. Mitt. zool. Mus. Berl., 48: 41-175.

Prater, T., J. Marchant \& J. Vuorinen, 1977. Guide to the identification and ageing of Holarctic waders: 1-168 (British Trust for Ornithology, Tring).

Schifferdi, A., P. Géroudet \& R. WinkLER, 1980. Verbreitungsatlas der Brutvögel der Schweiz: 1-462 (Schweiz. Vogelwarte, Sempach).

Sell, M., 1974. Zur Phänologie und Biometrie der Bartmeise (Panurus biarmicus) in Westfalen. Alcedo, 1: 1-15.

Sharrock, J. T. R., 1976. The atlas of breeding birds in Britain and Ireland: 1-477 (T. \& A. D. Poyser Ltd., Berkhamsted).

SluYs, R., 1982. Bearded Tits Panurus biarmicus in The Netherlands and England: comments on the hybridization theory. J. Orn., 123: 175-182.
SoKal, R. R. \& J. RohLF, 1969. Biometry: 1-776 (Freeman \& Comp., San Francisco).

Sprtzer, G., 1972. Jahreszeitliche Aspekte der Biologie der Bartmeise Panurus biarmicus. J. Orn., 113: 241275.

_-, 1973. Zur Verbreitung der Formen von Panurus biarmicus in der Westpaläarktis. Bonner zool. Beitr., 24: 291-301.

Tso-Hsin, C., 1976. Distributional list of Chinese birds: 1-1218 (Academica Sinica, Peking).

VAURIE, C., 1954. Systematic notes on Palearctic birds no. 6: Timeliinae and Paradoxornithinae. Am. Mus. Novit., 1669: 9-10.

- , 1959. The birds of the Palearctic fauna, Passeriformes: 1-762 (H. F. \& G. Witherby, London).

- , 1972. Tibet and its birds: 1-407 (H. F. \& G. Witherby, London).

Voous, K. H., 1960. Atlas of European birds: 1-284 (Nelson \& Elsevier, London/Amsterdam).

Yeatman, L., 1976. Atlas des Oiseaux nicheurs de France: 1-282 (Soc. Ornith. France, Paris). 
Appendix 1

Colour variation. Letters and numerals correspond with the standard specimens. Colour variation in each population is expressed as the percentage of birds corresponding with one of the standard specimens or intermediate between two standard specimens. Abbreviations of sample localities correspond with those given in table I.
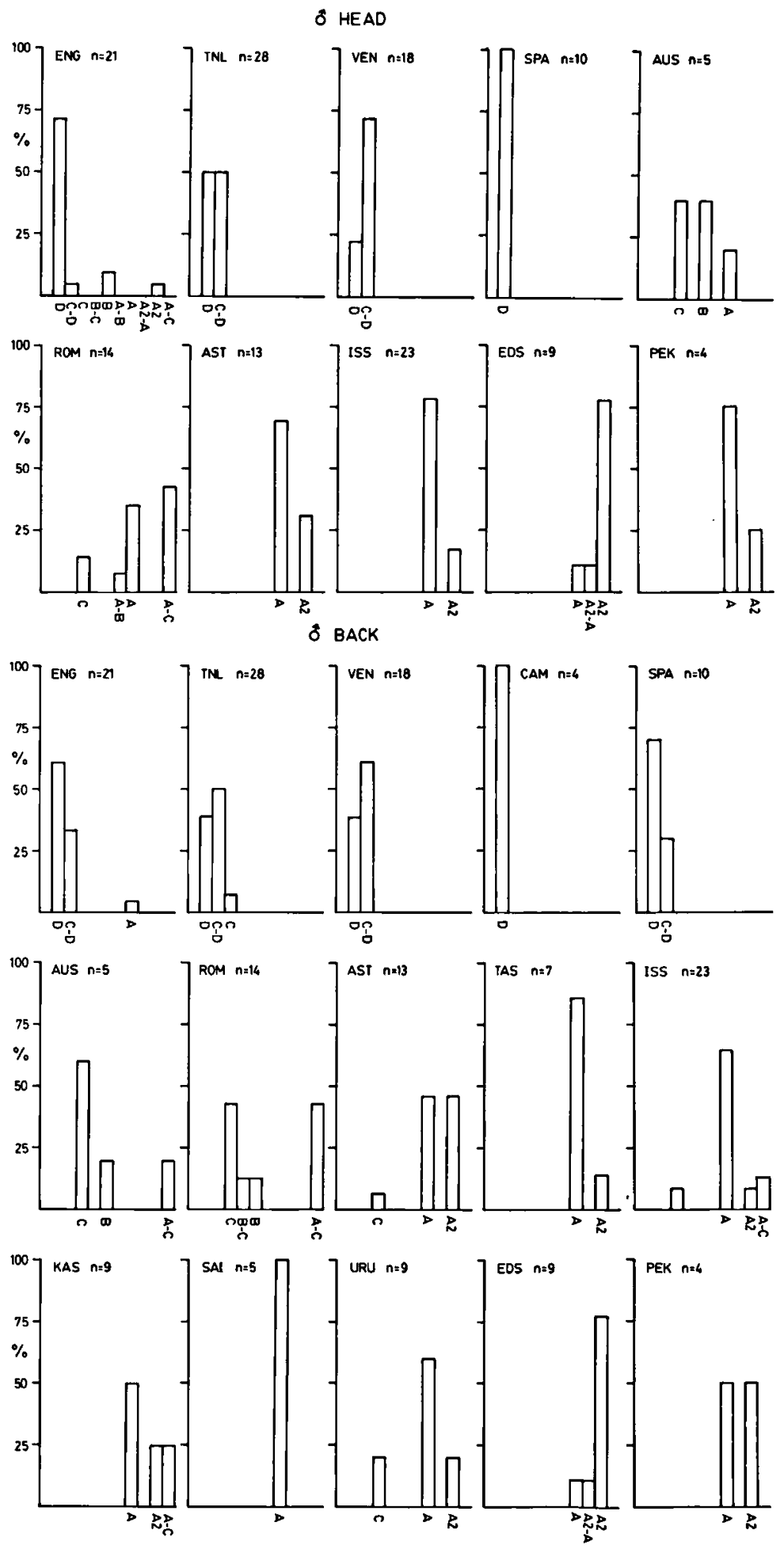
Appendix 1 (continued)
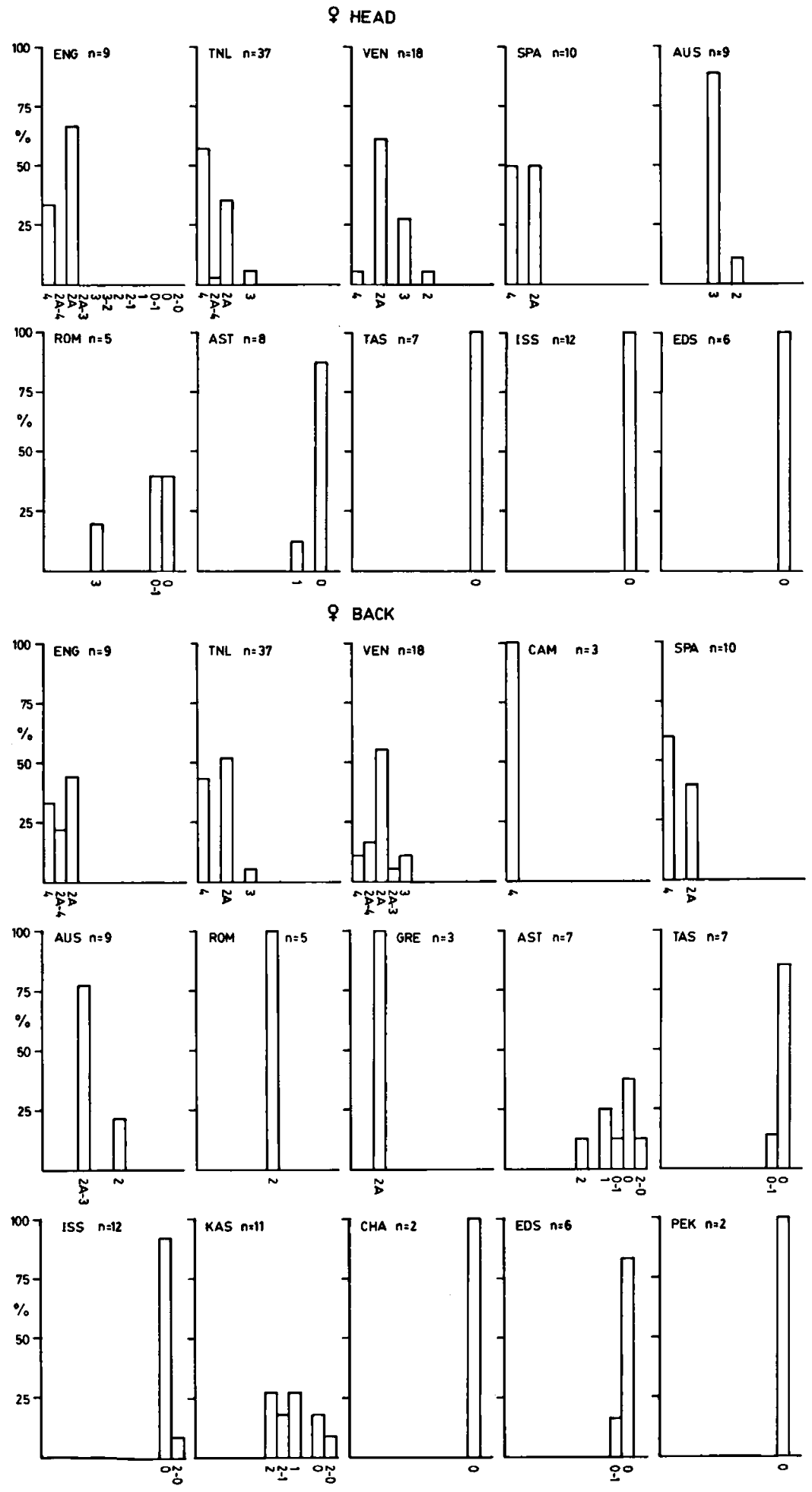
Appendix 2

Amount of streaking on head and back of females. Notation according to Mead \& Pearson (1974). Occurrence of a combination is expressed as the percentage of the total number of specimens examined. Abbreviations of sample localities correspond with those given in table I.

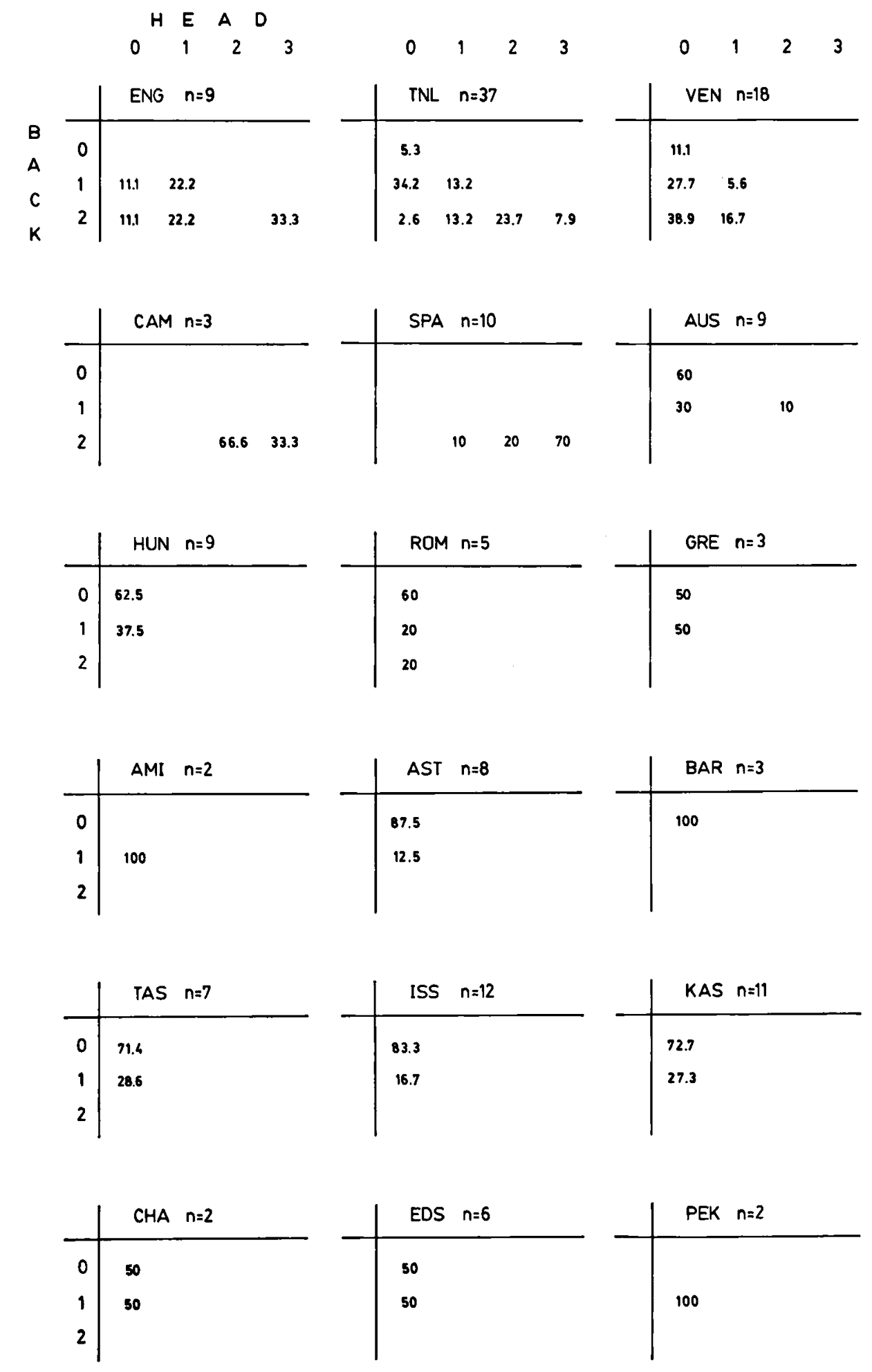


Appendix 3

Representative examples of outermost tail-feathers ( $\mathrm{t} 6)$. Black: black; hatched: greyish white; dotted: pale cinnamon. Abbreviations of sample localities correspond with those given in table I.
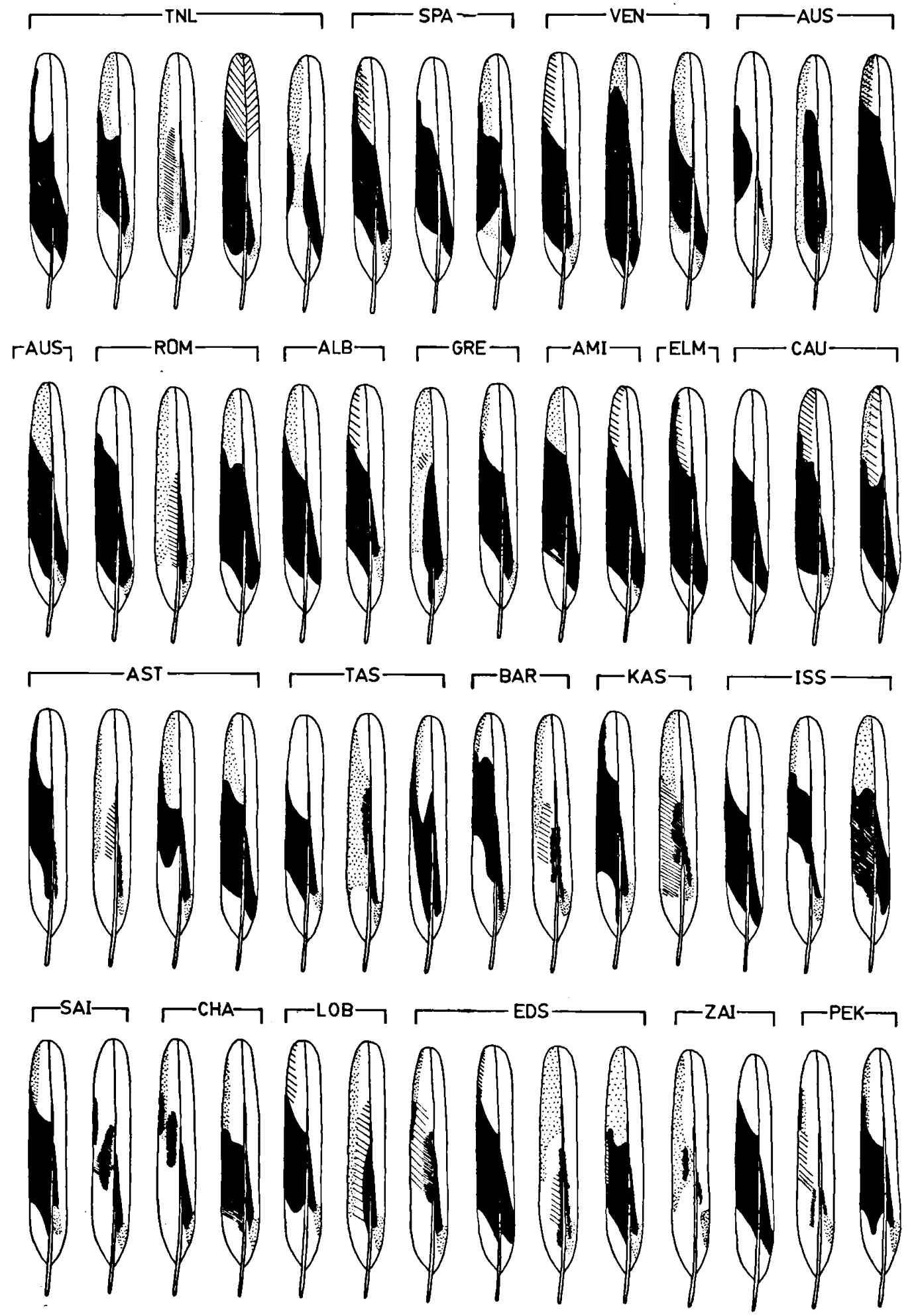